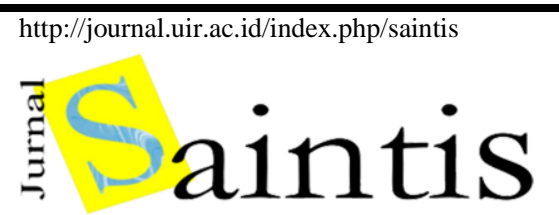

Volume 21 Nomor 01, April $2021: 45-52$

ISSN (Print)

$: 1410-7783$

ISSN (Online)

$: 2580-7110$

\title{
Analisis Sektor Basis dan Sektor Non-Basis dalam Upaya Peningkatan Sarana dan Prasarana Perkotaan di Kota Padang
}

\author{
Analysis of Basic and Non-Basic Sectors as Efforts to Improve the Urban Facilities and Infrastructure \\ in Padang
}

\author{
Aditia Nugraha Rusli ${ }^{1}$, Angelalia Roza ${ }^{2, *}$, Andi Mulya Rusli ${ }^{3}$ \\ ${ }^{1}$ Magister Pembangunan Wilayah dan Kota, Universitas Diponegoro \\ ${ }_{2}^{2} J u r u s a n$ Teknik Sipil, Fakultas Teknik, Institut Teknologi Padang \\ ${ }^{3}$ Direktorat Bina Marga, Kementrian Pekerjaan Umum dan Perumahan Rakyat
}

\begin{abstract}
* Penulis korespondensi : angelaliaroza@gmail.com
Tel.: +62-85-364-392830

Diterima: 6 Maret 2021; Direvisi: 29 April 2021; Disetujui: 30 April, 2021

DOI: 10.25299/saintis.2021.vol21(01).6537
\end{abstract}

\section{Abstrak}

Pembangunan berkelanjutan merupakan bagian dari fokus pembangunan daerah Kota Padang dengan tujuan menyediakan infrastruktur kota dan peningkatan perekonomian kota tahun 2019-2024. Pemerintah terus mengupayakan peningkatan Produk Domestik Regional Bruto (PDRB) Kota Padang dengan mengembangkan sektor kegiatan kota yang diimbangi dengan peningkatan sarana dan prasarana perkotaan. Penelitian ini bertujuan menganalisis sektor usaha yang belum mencapai kategori basis dan maju di Kota Padang. Metode yang digunakan dalam mengetahui sektor basis maupun non basis adalah metode location quotient (LQ). Sedangkan untuk mengetahui sektor maju atau mundur, digunakan analisis shift share. Dilakukan pula Analisis kependudukan melalui metode proyeksi trendline untuk memproyeksi peramalan penduduk pada tahun mendatang. Hasil analysis location quatien (LQ) menunjukkan terdapat dua sektor non basis di Kota Padang yaitu (1) sektor pertanian, kehutanan dan perikanan, (2) pertambangan dan penggalian. Selanjutnya, analisis shift-share menunjukkan terdapat empat sektor yang berada pada kategori mundur/ lamban yaitu sektor: (1) pertanian, (2) kehutanan dan perikanan, (3) industri pengolahan, pengadaan air, pengelolaan sampah, limbah dan daur ulang, (4) jasa keuangan dan asuransi. Berdasarkan trendline polynominal didapatkan model proyeksi perkiraan penduduk menurut persamaan $\mathrm{y}=$ $194.03 x^{2}+15535 x+815333$ dengan $R^{2}=0.9964$. Kebutuhan sarana prasarana untuk meningkatan kualitas hidup yang layak bagi warga Kota Padang diperkirakan meningkat secara dominan pada kelompok usia 20-24 tahun sebagai proyeksi angkatan kerja. Jumlahnya diprediksi sekitar 77.761 jiwa. Penelitian ini diharapkan bermanfaat dalam menentukan fokus penyediaan infrastruktur kota, agar sektor non basis dan sektor pada kategori mundur atau lambat dapat ditingkatkan menjadi kategori sektor basis dan maju.

Kata Kunci: $P D R B$, analisis $L Q$, analisis shift share

\section{Abstract}

Sustainable development is part of the regional development focus of Padang City to provide urban infrastructure and improve the city's economy in 2019-2024. The government continues to strive to increase the Gross Regional Domestic Product (PDRB) of the City of Padang by developing a sector of city activities towards improving urban facilities and infrastructure.This research supports the government's efforts in directing the development of the city of Padang. This study aims to analyze the business sector that has not reached the basic and advanced category in Padang City. The method used to determine the basis and non-base sectors is the location quotient (LQ) method. Meanwhile, to determine the forward or backward sector, shift-share analysis is used. Population analysis is also carried out through the trendline projection method to project population forecasts in the coming year. The results of the location quotient (LQ) analysis show that there are two non-basic sectors in the city of Padang, namely (1) agriculture, forestry, and fisheries, (2) mining and quarrying. Furthermore, the shift-share analysis shows that four sectors are in a slow category, namely the sectors: (1) agriculture, (2) forestry and fisheries, (3) processing industry, water supply, waste management, waste, and recycling, (4) financial and insurance services. Based on the polynomial trendline, the population forecast projection model is obtained according to the equation $y=-194.03 x^{2}+15535 x+815333$ with $R^{2}=0.9964$. The need for infrastructure and facilities to improve the quality of life that is feasible for the residents of Padang City is predicted to increase dominantly in the 20-24 year age group. The number is predicted to be around 77,761. It is hoped that this research will be useful in determining the focus of urban infrastructure provision, so that non-base sectors and sectors in the backward or later categories can be upgraded to the basic and advanced category.

Keywords: GRDP, LQ analysis, shift share analysis

\section{PENDAHULUAN}

Menurut laporan United Nations dan World Bank, lebih dari setengah populasi dunia sudah tinggal di kota, dan 2,5 miliar orang lainnya diproyeksikan pindah ke daerah perkotaan pada tahun 2050 [1]. Kondisi tersebut mendesak kota untuk mengagendakan peningkatan kualitas dan 
kuantitas infrastruktur. Banyak kota berjuang untuk meningkatkan sarana dan prasarana kota sebagai bentuk kontribusi pada sektor-sektor yang ada di kota. Sementara itu, kota juga harus menemukan pembiayaan yang tepat untuk merealisasikan proyek, dan memanfatkan potensipotensi yang ada yang ada di kota untuk menopang pertumbuhan ekonomi warga serta pembiayaan infrastruktur sarana dan prasarana. Pembiayaan strategi pembangunan kota, adalah perangkat yang secara khusus disiapkan untuk membantu pemerintah daerah mengumpulkan sumber daya internal dan eksternal untuk membiayai pelaksanaan proyek dan program prioritas [2]. Ini memberikan langkah-langkah, keterampilan dan sumber daya yang berguna untuk membantu proses pembiayaan City Development Strategy (CDS). Pengembangan tersebut nantinya akan meningkatkan sarana dan prasarana kota dalam memberikan pelayanan kepada masyarakat sehingga membuat kota menjadi berdaya saing dengan kota-kota lainnya.

Kota yang memadai dan dikelola dengan baik merupakan suatu elemen penting untuk mencapai aspek sehat dan sejahtera dan merupakan penyumbang kualitas hidup yang signifikan. Pada sisi lain daerah perkotaan di seluruh dunia mengalami masalah yang kompleks yaitu tantangan dalam pemanfaatan sektor-sektor yang menjadi sumber produktivitas yang mengarah pada peningkatan daya saing sehingga menciptakan kualitas hidup yang baik. Peningkatan sarana dan prasarana perkotaan merupakan suatu fungsi dari mengakomodir kebutuhan warga kota. Menurut [3] menegaskan bahwa infrastruktur fisik kawasan perkotaan merupakan fitur penting dalam pengalaman spasial kawasan perkotaan tersebut, dan oleh karena itu dalam pencapaian kota yang berkelanjutan sehingga penentu utama untuk berhasil menerapkan kawasan perkotaan berkelanjutan adalah dengan mengidentifikasi, menyediakan, dan mengelola infrastruktur utama di dalam kawasan tersebut. infrastruktur berkelanjutan yaitu struktur fisik dan organisasi yang saling berhubungan, layanan dan sistem yang mendukung fungsi sehari-hari masyarakat dan ekonominya didefinisikan sebagai komponen inti dari agenda kota berkelanjutan [4]. Poin dari konsep ini tidak hanya sekedar bekerlanjutan (sustainable) akan tetapi juga meliputi konsep kota ramah lingkungan (green) dan kota cerdas (smart city), sehingga dapat diartikan ketiga konsep saling berkaitan dalam pembangunan kota. Penelitian yang dilakukan di Kota Padang sangat perlu diterapkan konsep ini, apalagi Kota Padang merupakan ibukota Provinsi Sumatera Barat yang diharapkan mempunyai daya saing terhadap kotakota besar lainnya. $\begin{array}{ccr}\text { Upaya } & \text { pembangunan } & \text { perkotaan } \\ \text { mentargetkan } & \text { kecerdasan sosial, } & \text { ekonomi }\end{array}$ lingkungan dan masyarakatnya sebagai penunjang dan penopang tata kelola perkotaan dengan melakukan berbagai upaya peningkatan sarana dan prasarana terhadap ketiga konsep tersebut. Salah satu konsep strategi kota cerdas dipahami secara luas sebagai peningkatan kualitas hidup dan efektivitas manajemen kota [5]. Untuk mewujudkan hal tersebut dilakukan melalui perencanaan dan program infrastruktur dibeberapa kawasan pekotaan yang lebih terpadu dan sinergi antar sektor, antar wilayah dan antar stakeholder.

Menurut [6] kota cerdas diyakini bertumpu pada empat tema/pilar yaitu infrastruktur fisik, infrastruktur kelembagaan, infrastruktur sosial dan infrastruktur ekonomi. Tanggung jawab utama dari pilar-pilar tersebut adalah sebagai berikut:

1. Infrastruktur fisik bertujuan untuk memastikan keberlanjutan sumber daya dan kelancaran operasi kota. Ini terdiri dari infrastruktur yang diproduksi dan sumber daya alam. Kota pintar diwujudkan dengan bantuan jaringan objek pintar dan infrastruktur TIK yang berkualitas. Infrastruktur fisik juga diperluas ke energi pintar, renovasi bangunan, tata kota hijau, dan bangunan hijau.

2. Infrastruktur kelembagaan berfungsi untuk meningkatkan tata kelola kota pintar dengan berpartisipasi dalam pengambilan keputusan, strategi politik, tata kelola yang transparan, dan layanan sosial. Sangat penting untuk mendapatkan manfaat maksimal dari sumber daya manusia dan bekerja dengan warga untuk pemerintahan yang mudah serta perbaikan kota. Infrastruktur kelembagaan bekerja sama dengan pemerintah pusat maupun daerah untuk memanfaatkan manfaat maksimal dari kota pintar. Ini mengintegrasikan organisasi nasional, sipil, publik dan swasta untuk menyediakan interoperasi yang diperlukan antar layanan [7].

3. Infrastruktur sosial terdiri dari modal manusia, kualitas hidup dan modal intelektual. Infrastruktur sosial membantu menjaga keberlanjutan di kota pintar karena kesadaran, popularitas, dan komitmen warga berkontribusi dalam menjadikan konsep kota pintar populer[8].

4. Infrastruktur ekonomi mengacu pada pertumbuhan ekonomi dan lapangan kerja yang stabil sehingga dapat meningkatkan produktivitas kota dengan memanfaatkan praktik terbaik e-bisnis dan e-commerce[9]. 
Merujuk dari empat tema/pilar di_atas maka dapat dijadikan sebagai pedoman peningkatan sarana dan prasarana untuk infrastruktur fisik, infrastruktur kelembagaan, infrastruktur sosial dan infrastruktur ekonomi dalam upaya pencapaian konsep bekerlanjutan (sustainable), ramah lingkungan (green) dan kota cerdas (smart city).

Fokus penelitian terhadap Kota Padang yang merupakan ibukota provinsi Sumatera Barat dilihat dari angka PDRB Kota Padang pada tahun 2018 sebesar 57,5 T meningkat pada tahun 2019 menjadi 62,4 T [10]. Dari data tersebut terjadi peningkatan sebesar 7\% lebih. Untuk provinsi Sumatera Barat PDRB tahun 2018 sebesar $230 \mathrm{~T}$ meningkat pada tahun 2019 menjadi $246 \mathrm{~T}$ yang mana mengalami pertumbuhan sebesar 6,9\%. Dengan kondisi ini harus diiringi dengan memberikan perhatian lebih dalam melakukan pembangunan sarana dan prasarana untuk menunjang pelayanan kota terhadap sektor-sektor yang ada di Kota. Seiring dengan peningkatan sarana dan prasarana perkotaan hal ini akan membuat sektor-sektor tersebut mengalami kemajuan dan akan berdampak pada kualitas hidup warga kota yang semakin sejahtera. Persentase penduduk miskin di Kota Padang mengalami penurunan, pada tahun 2018 berada diangka 4,74\% sedangkan tahun 2019 sebesar 4,48\% [11]. Dengan kajian analisis sektor basis dan maupun sektor non basis maka nantinya dapat diketahui sektor non basis yang harus lebih ditingkatkan dengan cara salah satunya melakukan pembangunan sarana dan prasarana penunjang sektor tersebut. Selanjutnya juga memberikan kualitas hidup yang layak bagi warga kotanya.

\section{METODOLOGI}

Wilayah studi dalam penelitian ini adalah Kota Padang. Kota Padang merupakan kota yang terletak di pesisir Barat Pulau Sumatera dan sekaligus sebagai ibu kota Provinsi Sumatera Barat. Secara historis Kota Padang dahulunya merupakan salah satu pelabuhan utama dalam perdagangan teh, kopi, emas dan rempah-rempah. Seiring waktu terjadi perubahan dalam komoditi ekspor yang dulunya rempah-rempah berubah menjadi batu bara dan semen. Dengan potensi-potensi yang dimiliki tersebut menjadikan Kota Padang sebagai pusat perekonomian karena memiliki pendapatan per kapita tertinggi di Sumatera Barat. Selain itu dari segi fasilitas kotanya juga memiliki fasilitas yang lengkap dari kota dan kabupaten yang ada di Provinsi Sumatera Barat sebagai contoh fasilitas pendidikan, kesehatan maupun permukiman disebabkan jumlah penduduk Kota Padang yang lebih banyak dibandingkan kota-kota lain di Sumatera Barat.

Peta wilayah untuk daerah Kota Padang terlihat pada Gambar 1.

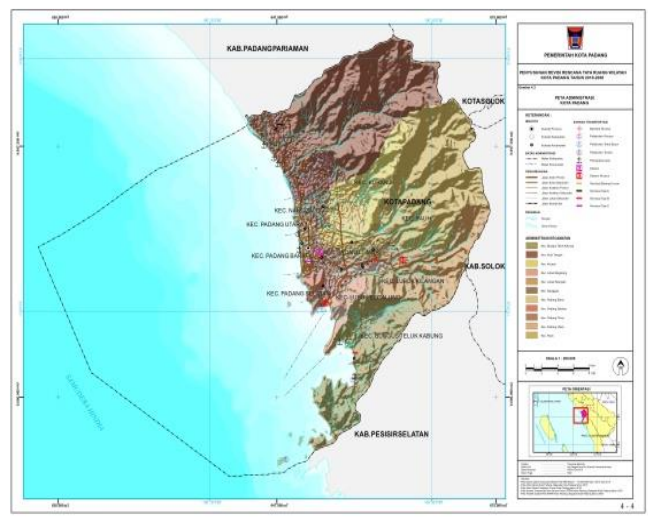

Sumber: RTRW Kota Padang 2010-2030

Gambar 1. Peta Administrasi Wilayah Studi Kota Padang

Proses mewujudkan pengembangan wilayah Kota Padang dengan mengacu konsep bekerlanjutan (sustainable), ramah lingkungan (green) dan kota cerdas (smart city) bertujuan untuk meningkatkan potensi yang ada pada kawasan-kawasan yang dinilai strategis. Untuk mencapai kondisi tersebut perlunya dukungan aksesibilitas yang optimal melalui penyediaan sarana dan prasarana fisik yang lebih baik untuk transportasi darat, laut maupun udara yang memungkinkan terjadinya perpindahan orang dan barang dalam jumlah besar dengan memperhatikan aspek efisien, aman dan nyaman bagi pengguna moda khususnya.

Pada penelitian ini objek penelitian adalah Kota Padang dengan menggunakan data sekunder berupa data pertumbuhan ekonomi Produk Domestik Regional Bruto (PDRB) Provinsi Sumatera Barat tahun 2019 dan pertumbuhan ekonomi Produk Regional Bruto Kota Padang tahun 2019. Analisis yang digunakan dalam penelitian ini menggunakan analisis sektor bidang ekonomi metode Location Quotien (LQ) untuk melihat sektor basis maupun non basis di Kota Padang dalam kaitannya dengan tujuan untuk mengetahui sektor non basis yang akan dilakukan peningkatan sarana dan prasarana penunjang sektor tersebut. Metode Location Quotien adalah suatu teknik yang sederhana, cepat dan tepat hal ini karena metode ini dapat digunakan secara berulang, dan analisis ini berfungsi sebagai mengkaji sektor basis pada suatu wilayah berdasarkan Produk Domestik Regional Bruto (PDRB) sebagai indikatornya [12].

Upaya penting dalam mendukung kehidupan masyarakat di suatu wilayah dengan melakukan evalusi sumber daya atau sektor untuk dioptimalkan menjadi pemanfaatan. Tahapan dalam pengelolaan sumber daya berfungsi untuk memastikan sektor-sektor tersebut tersedia dan bekerlanjutan. Analisis tentang sektor basis merupakan upaya dalam mengambil kebijakan dalam pembangunan regional [13]. Penilaian aglomerasi tingkat dan pertumbuhan masingmasing sektor dalam pembangunan ekonomi dapat 
memberikan wawasan yang lebih baik bagi para pemangku kepentingan baik lokal maupun badan pemerintah ataupun swasta untuk meningkatkan pengelolaan sektor-sektor tersebut secara berkelanjutan [14].

Ada empat teknik dasar dalam analisis basis ekonomi yang dapat digunakan, terutama jika ketersedian data menjadi kendala dalam menggunakan analisis ekonomi yang lebih kompleks seperti menggunkan metode survey, metode asumsi, metode location quotient (LQ) dan metode persyaratan minimum. Mendefenisikan LQ sebagai alat analisis dasar untuk menghasilkan koefisien atau ekspresi sederhana tantang seberapa baik representasi industry tertentu di wilayah studi tertentu [15]. Location quotient (LQ) telah ditetapkan secara luas dalam geografi ekonomi dan ekonomi regional sejak tahun 1940-an karena tidak tersedianya data aliran perdagangan antara wilayah [16].

$$
\mathbf{L Q}=\frac{p s / p l}{P s / P l}
$$

Keterangan :

$\mathrm{LQ}=$ Location Quotient

Ps = Produksi/kesempatan kerja sektor $\mathrm{i}$, pada tingkat lokal

pl = Produksi/kesempatan kerja total, pada tingkat lokal

Ps = Produksi/kesempatan kerja sektor $\mathrm{i}$, pada tingkat regional

$\mathrm{Pl}$ = Produksi/kesempatan kerja total, pada tingkal regional

Identifikasi sektor strategis dilakukan tehadap nilai $L Q$ dengan ketentuan jika nilai $L Q \geq 1$ maka dapat dikategorikan sektor baisis dan sebaliknya apabila nilai LQ $<1$ maka dapat dikategorikan sektor tersebut bukanlah sektor basis.

Analisis berikutnya adalah analisis Shift Share. Analisis ini memungkinkan penilaian sektor tertentu di wilayah tertentu selama periode waktu yang relatif terhadap sektor-sektor yang terkait dengannya [17]. Secara umum analisis ini mengacu pada asumsi pertumbuhan sektor-sektor ekonomi wilayah daerah perencanaan dengan wilayah acuan, Kemudian, ditelit pula kondisi sektor-sektor yang mengalami perubahan atau pertumbuhan kinerja ekonomi pada daerah (lokasi perencanaan). Selain itu analisis ini dapat melihat sektor lamban dan sektor maju yang nantinya dapat dijadikan pertimbangan dalam penyedian lapangan kerja bagi warga di wilayah tersebut. Rumusan analisis shift share dapat ditunjukan dalam perhitungan sederhana sebagai berikut [18] :

$$
\begin{aligned}
& \mathrm{PE}=\mathrm{KPN}+\mathrm{KPP}+\mathrm{KPPW} \\
& \mathrm{PE}=\left(\frac{Y_{t}}{Y_{0}}-1\right)+\left(\frac{Y i t}{Y_{i o}}-\frac{Y_{t}}{Y_{0}}\right)+\left(\frac{\text { yit }}{\text { yio }}-\frac{Y_{t}}{Y_{0}}\right) \\
& \mathrm{PE}=[\mathrm{Ra}-1]+[R i-R a]+[r i-R a]
\end{aligned}
$$

Keterangan :

Yo = indikator ekonomi wilayah nasional, awal tahun analisis.

Yit = indikator ekonomi wilayah nasional sektor i, akhir tahun analisis.

Yio = indikator ekonomi wilayah nasional sektor i ,awal tahun analisis.

yit = indikator ekonomi wilayah lokal sektor i, akhir tahun analisis.

yio = indikator ekonomi wilayah lokal sektor $\mathrm{i}$, awal tahun analisis.

Dijelaskan dalam buku [19] untuk Komponen Pertumbuhan Nasional (KPN) merupakan komponen share dan sharing disebut sebagai national share. KPN adalah perubahan produksi atau kesempatan kerja dalam suatu wilayah disebabkan karena terjadi perubahan produksi secara umum, sehingga dapat menjadi acuan dalam mengambil kebijakan ekonomi nasional dan kebijakan lain yang mampu mempengaruhi sektor perekonomian dalam suatu wilayah. Komponen Pertumbuhan Proposional (KPP) adalah penyimpangan dari nasional share dari suatu suatu wilayah, Untuk nilai KPP > 0 maka sektor tersebut dapat dikategorikan mengalami pertumbuhan yang cepat. Sebaliknya apabila $\mathrm{KPP}<0$ maka sektor tersebut dikategorikan sebagai sektor yang mengalami pertumbahan yang lambat. Komponen Pertumbuhan Pangsa Wilayah (KPPW), yang dikenal pula sebagai komponen lokasional atau regional. Dalam hal ini KPPW mengalami perubahan produksi dikarenakan keunggulan komparatif daerah tersebut, dukungan kelembagaan, prasarana sosial ekonomi serta akibat dari kebijakan lokal pada daerah itu sendiri. Untuk KPPW > 0 maka dikategorikan sektor tersebt memiliki keunggulan komparatif sedangkan nilai KPPW $<0$ maka sektor tersebut tidak mempunyai keunggulan komparati yang diartikan tidak dapat bersaing

\section{$P S=K P P+K P P W$}

Dengan ketentuan nilai PS $\geq 0$, maka sektor tersebut dapat dikategorikan maju dan apabila nilai PS $<0$, maka sektor tersebut dapat dikategorikan mundur.

Analisis berikutnya dilakukan terhadap jumlah penduduk dengan menggunakan metoda trendline untuk mengetahui perkiraan jumlah penduduk di masa yang akan datang dan pengelompokan berdasarkan usia yang bisa nantinya dipersiapkan untuk masa yang akan datang pada wilayah tersebut. Metode deret berkala (trendline) mempunyai karateristik data yang dianalisis merupakan data yang bersifat deret selain itu juga data yang menujukan waktu yang berkala [20]. Periode yang digunakan dalam trendline dapat meliputi tahunan, bulanan, semester, kuartal. Tujuan dari penggunaan metode ini antara lain adalah [20] melakukan peramalan deret berkala sehingga dapat menemukan pola 
deret dan mengekstrapolasikan pola yang didapatkan tersebut ke masa mendatang.

\section{HASIL DAN DISKUSI}

\section{Location Quatien (LQ)}

Dalam penelitian ini menggunakan Metode Location Quatien (LQ) untuk mengetahui secara detail sektor atau kegiatan ekonomi tertentu di suatu wilayah perencanaan. Variabel pengukuran yang digunakan pada penelitian ini adalah adalah variabel Produk Domestik regional Bruto (PDRB) wilayah Kota Padang dan PDRB daerah acuan yang dalam hal ini adalah Provinsi Sumatera Barat sebagai acuan untuk mendapakan melihat sektor basis wilayah perencanaan, dimana untuk melihat komoditas yang berpotensi mendukung pengembangan wilayah.

Tabel. 1 Nilai LQ Masing-Masing Sektor di Kota Padang dan Provinsi Sumatera Barat Tahun 2019

\begin{tabular}{|c|c|c|c|c|}
\hline Sektor & $\begin{array}{l}\text { PDRB Kota } \\
\text { Padang } \\
\text { (Rp) }\end{array}$ & $\begin{array}{l}\text { PDRB Provinsi } \\
\text { Sumatera } \\
\text { Barat } \\
\text { (Rp) }\end{array}$ & LQ & KET \\
\hline $\begin{array}{l}\text { Pertanian, } \\
\text { Kehutanan dan } \\
\text { Perikanan }\end{array}$ & $3.307 .736,23$ & $54.639 .893,00$ & 0.239 & $\begin{array}{l}\text { NON } \\
\text { BASIS }\end{array}$ \\
\hline $\begin{array}{l}\text { Pertambangan } \\
\text { dan penggalian }\end{array}$ & $2.010 .262,17$ & $10.576 .705,18$ & 0.750 & $\begin{array}{l}\text { NON } \\
\text { BASIS }\end{array}$ \\
\hline $\begin{array}{l}\text { Industri } \\
\text { Pengolahan }\end{array}$ & $7.334 .221,67$ & $20.630 .720,52$ & 1.403 & BASIS \\
\hline $\begin{array}{l}\text { Pengadaan } \\
\text { Listrik dan Gas }\end{array}$ & $68.201,79$ & $263.753,97$ & 1.020 & BASIS \\
\hline $\begin{array}{l}\text { Pengadaan Air, } \\
\text { Pengelolaan } \\
\text { Sampah, } \\
\text { Limbah dan } \\
\text { Daur Ulang }\end{array}$ & $89.561,92$ & $222.769,91$ & 1.586 & BASIS \\
\hline Konstruksi & $6.567 .228,26$ & $24.863 .413,70$ & 1.042 & BASIS \\
\hline $\begin{array}{l}\text { Perdagangan } \\
\text { Besar dan } \\
\text { Enceran, } \\
\text { Reparasi Mobil } \\
\text { dan Sepeda } \\
\text { Motor }\end{array}$ & $10.578 .245,11$ & $38.929 .614,99$ & 1.072 & BASIS \\
\hline $\begin{array}{l}\text { Transportasi } \\
\text { dan } \\
\text { Pergudangan }\end{array}$ & $10.722 .690,46$ & $31.041 .492,60$ & 1.363 & BASIS \\
\hline $\begin{array}{l}\text { Penyediaan } \\
\text { Akomodasi } \\
\text { dan Makan } \\
\text { Minum }\end{array}$ & $935.094,36$ & $3.509 .548,64$ & 1.051 & BASIS \\
\hline $\begin{array}{l}\text { Informasi dan } \\
\text { Komunikasi }\end{array}$ & $4.612 .043,83$ & $14.332 .436,19$ & 1.270 & BASIS \\
\hline $\begin{array}{l}\text { Jasa Keuangan } \\
\text { dan Ansuransi }\end{array}$ & $3.097 .277,64$ & 7.153.612,99 & 1.363 & BASIS \\
\hline Real Estate & $1.939 .807,10$ & $4.941 .486,65$ & 1.051 & BASIS \\
\hline $\begin{array}{l}\text { Jasa } \\
\text { Perusahaan }\end{array}$ & $941.293,81$ & $1.093 .577,49$ & 1.270 & BASIS \\
\hline $\begin{array}{l}\text { Administrasi } \\
\text { Pemerintahan, } \\
\text { Pertahanan } \\
\text { dan Jaminan } \\
\text { Sosial Wajib }\end{array}$ & $4.195 .215,60$ & $15.094 .924,78$ & 1.708 & BASIS \\
\hline $\begin{array}{l}\text { Jasa } \\
\text { Pendidikan }\end{array}$ & $3.278 .696,74$ & $10.698 .965,12$ & 1.209 & BASIS \\
\hline $\begin{array}{l}\text { Jasa Kesehatan } \\
\text { dan Kegiatan } \\
\text { Sosial }\end{array}$ & $1.018 .604,14$ & $3.501 .720,89$ & 1.148 & BASIS \\
\hline Jasa Lainnya & $1.761 .373,37$ & $4.928 .088,15$ & 1.410 & BASIS \\
\hline Total & $62.457 .554,20$ & $246.422 .724,79$ & & \\
\hline
\end{tabular}

Sumber: Hasil Analisis, 2021
Apabila nilai LQ $<1$, dapat ditafsirkan bahwa kegiatan sektor tersebut masih lemah, belum mapu memenuhi kebutuhan permintaan pasar di dalam wilayahnya sendiri dan juga belum bisa untuk diekspor ke luar wilayah tersebut. Dengan demikian daerah tersebut masih membutuhkan atau mendatangkan produk/sektor daerah lain. Dalam menganalisis Nilai LQ di wilayah Kota Padang, PDRB Sumatera Barat dijadikan sebagai daerah acuan. Berdasarkan perhitungan di atas, maka untuk sektor basis yaitu kategori nilai $L Q \geq 1$ antara lain adalah sebagai berikut:

1. Industri pengolahan

2. Pengadaan listrik dan gas

3. Pengadaan air, pengelolaan sampah, limbah dan daur ulang

4. Konstruksi

5. Perdagangan besar dan eceran; reparasi mobil dan sepeda motor

6. Transportasi dan pergudangan

7. Penyediaan akomodasi dan makan minum

8. Informasi dan komunikasi

9. Jasa keuangan dan asuransi

10. Real estate

11. Jasa perusahaan

12. Administrasi pemerintahan, pertahanan dan jaminan sosial wajib

13. Jasa pendidikan

14. Jasa kesehatan dan kegiatan sosial

15. Jasa lainnya

Sedangkan sektor-sektor yang lain masih kurang dari 1 atau dikategorikan sektor non basis adalah sebagai berikut: (1) Pertanian, kehutanan dan perikanan (2) Pertambangan dan penggalian. Maka mengacu pada hasil analisis location quotient ini, maka pembangunan peningkatan sarana prasarana perkotaan, perlu lebih diprioritaskan untuk sektor non basis tersebut.

\section{Analisis Shift Share}

Analisis shift-share adalah metode dekomposisi pertumbuhan yang digunakan untuk meningkatkan pemahaman tentang perubahan dalam sistem dengan membandingkan perubahan di wilayah yang diminati dengan perubahan di wilayah referensi yang relevan [21]. Dalam penelitian ini analisis shift share digunakan untuk mengetahui dan mengidentifikasi sektor-sektor ekonomi yang mengalami perkembangan maju maupun belum berkembang. Sehingga nantinya sektor yang belum berkembang baik bisa menjadi pedoman dalam mengambil kebijakan untuk diberikan prioritas lebih dalam pembangunan sarana dan prasarana sektor tersebut. 
Tabel. 2 Hasil Perhitungan Komponen KPN, KPP,

\begin{tabular}{|c|c|c|c|c|c|}
\hline Sektor & $\begin{array}{l}\text { KPN } \\
\text { Ra-1 }\end{array}$ & $\begin{array}{c}\text { KPP } \\
\text { Ri-Ra }\end{array}$ & $\begin{array}{c}\text { KPPW } \\
\text { Ri-Ra }\end{array}$ & $\begin{array}{c}\text { PS } \\
\text { KPP+ } \\
\text { KPPW }\end{array}$ & KET \\
\hline $\begin{array}{l}\text { Pertanian, } \\
\text { Kehutanan } \\
\text { dan } \\
\text { Perikanan }\end{array}$ & 0.0689 & 0.0455 & 0.0325 & -0.0130 & MUNDUR \\
\hline $\begin{array}{l}\text { Pertambang } \\
\text { an dan } \\
\text { penggalian }\end{array}$ & 0.0689 & 0.0067 & 0.0228 & 0.0295 & MAJU \\
\hline $\begin{array}{l}\text { Industri } \\
\text { Pengolahan }\end{array}$ & 0.0689 & $\begin{array}{c}- \\
0.0850\end{array}$ & -0.0990 & -0.1840 & MUNDUR \\
\hline $\begin{array}{l}\text { Pengadaan } \\
\text { Listrik dan } \\
\text { Gas }\end{array}$ & 0.0689 & $\begin{array}{c}- \\
0.0510\end{array}$ & 0.0686 & 0.0176 & MAJU \\
\hline $\begin{array}{l}\text { Pengadaan } \\
\text { Air, } \\
\text { Pengelolaan } \\
\text { Sampah, } \\
\text { Limbah dan } \\
\text { Daur Ulang }\end{array}$ & 0.0689 & $\begin{array}{c}- \\
0.0019\end{array}$ & -0.0145 & -0.0164 & MUNDUR \\
\hline Konstruksi & 0.0689 & 0.0501 & 0.0158 & 0.0659 & MAJU \\
\hline $\begin{array}{l}\text { Perdagangan } \\
\text { Besar dan } \\
\text { Enceran, } \\
\text { Reparasi } \\
\text { Mobil dan } \\
\text { Sepeda } \\
\text { Motor }\end{array}$ & 0.0689 & 0.0340 & 0.0234 & 0.0573 & MAJU \\
\hline $\begin{array}{l}\text { Transportasi } \\
\text { dan } \\
\text { Pergudangan }\end{array}$ & 0.0689 & 0.0053 & 0.0305 & 0.0252 & MAJU \\
\hline $\begin{array}{l}\text { Penyediaan } \\
\text { Akomodasi } \\
\text { dan Makan } \\
\text { Minum }\end{array}$ & 0.0689 & 0.0466 & 0.0596 & 0.1063 & MAJU \\
\hline $\begin{array}{l}\text { Informasi } \\
\text { dan } \\
\text { Komunikasi }\end{array}$ & 0.0689 & 0.0675 & 0.0878 & 0.1553 & MAJU \\
\hline $\begin{array}{l}\text { Jasa } \\
\text { Keuangan } \\
\text { dan } \\
\text { Ansuransi }\end{array}$ & 0.0689 & $\begin{array}{c}- \\
0.0366\end{array}$ & -0.0222 & -0.0588 & MUNDUR \\
\hline Real Estate & 0.0689 & 0.0259 & 0.0172 & 0.0431 & MAJU \\
\hline $\begin{array}{l}\text { Jasa } \\
\text { Perusahaan }\end{array}$ & 0.0689 & 0.0220 & 0.04480 & 0.0701 & MAJU \\
\hline $\begin{array}{l}\text { Administrasi } \\
\text { Pemerintaha } \\
\text { n, } \\
\text { Pertahanan } \\
\text { dan Jaminan } \\
\text { Sosial Wajib }\end{array}$ & 0.0689 & 0.0375 & 0.0631 & 0.1007 & MAJU \\
\hline $\begin{array}{l}\text { Jasa } \\
\text { Pendidikan }\end{array}$ & 0.0689 & 0.0358 & 0.0526 & 0.0884 & MAJU \\
\hline $\begin{array}{l}\text { Jasa } \\
\text { Kesehatan } \\
\text { dan Kegiatan } \\
\text { Sosial }\end{array}$ & 0.0689 & 0.0271 & 0.0533 & 0.0804 & MAJU \\
\hline Jasa Lainnya & 0.0689 & 0.0392 & 0.0764 & 0.1156 & MAJU \\
\hline Total & 0.0689 & 0.0000 & 0.0169 & 0.0169 & \\
\hline
\end{tabular}

Merujuk Tabel 2, maka sektor unggulan adalah sektor yang mempunyai nilai PS positif. Sebaliknya PS yang bernilai negatif dapat dikategorikan sebagai sektor kurang maju. Maka terdapat 4 sektor saja yang sedikit mundur/ lamban dalam pertumbuhannya. Sedangkan sektor lainnya termasuk ke dalam sektor unggul yang ada di Kota Padang.
Pada sektor pertanian, kehutanan dan perikanan, permasalahan yang terjadi adalah banyaknya lahan produktif yang berubah menjadi lahan terbangun. Pada sektor industri pengolahan, permasalahan terjadi akibat tidak adanya kawasan industri sehingga belum dapat mengayomi potensi industri yang ada di Kota Padang. Pada sektor pengadaan air, pengelolaan sampah, limbah dan daur ulang, kendalanya adalah sektor tersebut belum dikelola dengan optimal. Sedangkan pada sektor jasa keuangan dan asuransi, permasalahannya adalah tingginya ketergantungan pemerintah daerah dalam hal mengandalkan kebijakan pemerintah pusat akibat dari minimnya inovasi dari pemerintah daerah.

Dari empat sektor mundur tersebut, ternyata sektor pertanian, kehutanan dan perikanan yang memperoleh nilai terendah. Permasalahan ini terjadi akibat alih fungsi lahan pertanian, kehutanan, dan perikanan menjadi lahan terbangun seperti menjadi lahan permukiman yang akibat dari pertumbuhan penduduk yang terus meningkat setiap tahunnya. Sebaliknya sektor yang dominan di Kota Padang terlihat di sektor informasi dan komunikasi yang sudah menjadi kebutuhan primer warga kota pada saat sekarang khususnya dikarenakan ibukota provinsi.

\section{Analisis Kependudukan}

Untuk analisis kependudukan dilakukan dengan menggunakan metode proyeksi trendline untuk memproyeksi peramalan penduduk pada tahun yang akan datang dengan kecendrungan terjadi pertambahan atau terjadi pengurangan per tahunnya.

Tabel. 3 Jumlah Penduduk di Kota Padang

\begin{tabular}{cc}
\hline Tahun & $\begin{array}{c}\text { Jumlah Penduduk Kota } \\
\text { Padang (jiwa) }\end{array}$ \\
\hline 2010 & 833.562 \\
\hline 2011 & 844.316 \\
\hline 2012 & 854.336 \\
\hline 2013 & 876.678 \\
\hline 2014 & 889.646 \\
\hline 2015 & 902.413 \\
\hline 2016 & 914.968 \\
\hline 2017 & 927.168 \\
\hline 2018 & 939.112 \\
\hline 2019 & 950.871 \\
\hline
\end{tabular}

Sumber: BPS Kota Padang

Analisis trendline dilakukan dengan menggunakan jenis-jenis grafik seperti polynominal, eksponensial, logaritmic dan linear maka didapatkan nilai R square dan persamaan dari masing-masing jenis grafik tersebut. Dari hasil analisis dipilih nilai $\mathrm{R}$ square yang mendekati 1 atau yang mempunyai nilai paling besar. Berikut hasil rekap nilai $\mathrm{R}$ square dari berbagai jenis trendline 
Tabel. 4 Hasil Rekap Analsisi Trendline

\begin{tabular}{lll}
\hline $\begin{array}{c}\text { Jenis } \\
\text { Trendline }\end{array}$ & \multicolumn{1}{c}{ Persamaan } & \multicolumn{1}{c}{$\begin{array}{c}\text { Nilai R } \\
\text { square }\end{array}$} \\
\hline Eksponesial & $\mathrm{y}=821621 \mathrm{e} 0.015 \mathrm{x}$ & $\mathrm{R}^{2}=0.9933$ \\
\hline Linier & $\mathrm{y}=13401 \mathrm{x}+819602$ & $\mathrm{R}^{2}=0.9951$ \\
\hline Logaritmic & $\mathrm{y}=53010 \ln (\mathrm{x})=813239$ & $\mathrm{R}^{2}=0.9127$ \\
\hline Polynominal & $\begin{array}{l}\mathbf{y}=\mathbf{- 1 9 4 . 0 3 \times 2}+\mathbf{1 5 5 3 5 x} \\
+\mathbf{8 1 5 3 3 3}\end{array}$ & $\mathbf{R}^{2}=\mathbf{0 . 9 9 6 4}$ \\
\hline
\end{tabular}

Sumber: Hasil Analisis, 2021

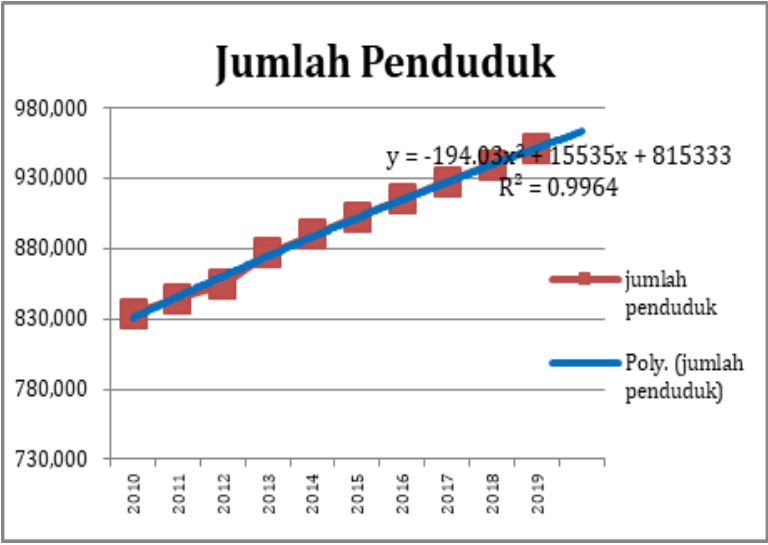

Sumber: Hasil Analisis, 2021

Gambar 2. Grafik Trendline Polynominal (jiwa)

Hasil analisis menggunakan analisis trendline polynominal menghasilkan nilai $\mathrm{R}$ square terbaik $\left(\mathrm{R}^{2}=0.9964\right)$. Pada grafik 1 dapat dilihat bahwa pertumbuhan jumlah penduduk Kota Padang terus mengalami peningkatan pada tahun mendatang. Berdasarkan trendline polynominal didapatkan model proyeksi perkiraan penduduk menurut persamaan $\mathbf{y}=\mathbf{- 1 9 4 . 0 3} x^{2}+\mathbf{1 5 5 3 5 x}+\mathbf{8 1 5 3 3 3}$.

Melalui persamaan tersebut maka didapatkan proyeksi perkiraan penduduk di Kota Padang pada tahun mendatang. Sebagai perkiraan pada tahun 2025 untuk jumlah penduduk kota padang yaitu sebesar 1.082.439 jiwa. Artinya perkiraan pertumbuhan jumlah penduduk di Kota Padang sebesar $6 \quad \% \quad$ sampai $7 \quad \%$ sehingga diperlukan persiapan bagi stakeholder terkait untuk kemungkinan antisipasi kenaikan angka penganguran maupun angka kemiskinan yang terjadi di Kota Padang

Komposisi umur penduduk yang didapatkan dari Badan Pusat Statistik Kota Padang pada tahun 2017 sebagaimana terlihat pada Gambar 3, mengindikasikan mayoritas penduduk berada pada rentang usia 20-25 tahun dengan total 77.761 jiwa. Lebih rinci, menurut kelompok umur tersebut, jenis kelamin laki-laki berjumlah 39.967 jiwa dan perempuan berjumlah 37.794 jiwa.

Kelompok umur yang dominan terlihat antara 20 tahun sampai 24 tahun merupakan kelompok umum peralihan dari fase pendidikan menjadi fase kelompok umur yang memasuki persiapan dunia kerja. Dengan mengacu pada hasil analisis shift-share, dimana menurut penulis sektor industri yang seharusnya mampu membuka peluang menyerap tenaga kerja yang lebih banyak.
Akan tetapi dari hasil analisis shift-share menunjukan sektor ini mundur sehingga perlu suatu ketersedian sarana dan prasarana penunjang sektor ini agar optimal dalam penyerapan tenaga kerja yang berasal dari kelompok umur 20 tahun sampai 24 tahun. Disamping perlu juga perhatian pada kelompok umur lainnya seperti balita maupun lansia yang perlu disiapkan sedemikian rupa tatanan kota untuk menujang kehidupan mereka yang layak sehingga menjadi kota layak untuk semua umur.

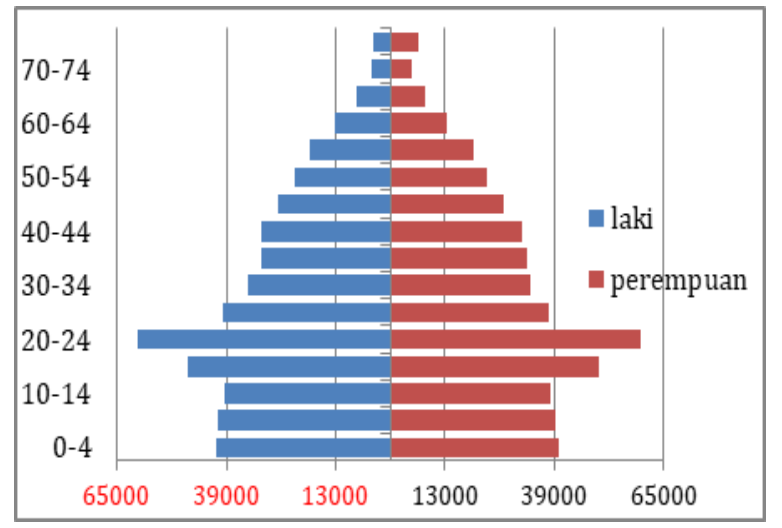

Sumber: BPS Kota Padang

Gambar 3. Jumlah Penduduk menurut Kelompok Umur Tahun 2017

\section{KESIMPULAN}

Berdasarkan hasil analysis location quatien (LQ) dapat dijelaskan bahwa Kota Padang memiliki dua sektor non basis yaitu; (1) pertanian, kehutanan dan perikanan serta (2) pertambangan dan penggalian. Sementara itu, hasil analisis shiftshare menunjukkan terdapat 4 sektor saja yang sedikit mundur/ lamban dalam pertumbuhannya yaitu sektor (1) pertanian, (2) kehutanan dan perikanan, (3) industri pengolahan, pengadaan air, pengelolaan sampah, limbah dan daur ulang, (4) jasa keuangan dan asuransi. Dikaitkan dengan analisis kependudukan, melalui regresi polynomial trendline diperkiraan pertumbuhan penduduk Kota Padang mencapai 1.082.439 jiwa pada tahun 2025 dengan p-eningkatan 6-7 \%. Maka, hasil analisis tersebut bisa dijadikan pertimbangan dalam menentukan fokus penyediaan infrastruktur kota, terutama pada sektor kategori non basis dan sektor yang mundur/ lamban. Dengan demikian pembangunan sarana dan prasarana dapat lebih tepat sasaran sebagai upaya percepatan perubahan status menuju kategori sektor basis dan maju. Penelitian lanjutan perlu diarahkan pada upaya optimalisai sektor unggulan Kota Padang sebagai persiapan dalam memberikan kualitas hidup yang layak untuk warga Kota Padang yang terus bertambah terutama pada rentang usia 20-24 tahun sebagai proyeksi penyerapan tenaga kerja. Penelitian lanjutan perlu mengatasi kelemahan data pada penelitian ini, khususnya data PDRB Kota 
Padang yang masih menggunakan data release tahun 2019.

\section{REFERENSI}

[1] ONU, World Urbanization Prospects, vol. 12. 2018.

[2] C. Kinuthia-Njenga et al., Financing Urban Development Around Lake Victoria: A Toolkit. UN-Habitat, 2006.

[3] M. Kathy, "Urban facilities management: a means to the attainment of sustainable cities?," J. Facil. Manag., vol. 11, no. 3, Jan. 2013, doi: 10.1108/jfm.2013.30811caa.001.

[4] UN-Habitat, Habitat III Issue Papers: Urban Governance, Capacity and Institutional Development. 2016.

[5] G. Masik, I. Sagan, and J. W. Scott, "Smart City strategies and new urban development policies in the Polish context," Cities, vol. 108, p. 102970, 2020, doi: https://doi.org/10.1016/j.cities.2020.1029 70.

[6] B. Bhushan, A. Khamparia, K. M. Sagayam, S. K. Sharma, M. A. Ahad, and N. C. Debnath, "Blockchain for smart cities: A review of architectures, integration trends and future research directions," Sustain. Cities Soc., vol. 61, p. 102360, 2020, doi: https://doi.org/10.1016/j.scs.2020.102360.

[7] R. Kitchin, "The real-time city? Big data and smart urbanism," GeoJournal, vol. 79, no. 1, pp. 1-14, 2014.

[8] T. Nam and T. A. Pardo, "Conceptualizing smart city with dimensions of technology, people, and institutions," in Proceedings of the 12th annual international digital government research conference: digital government innovation in challenging times, 2011, pp. 282-291.

[9] P. Lombardi, S. Giordano, H. Farouh, and W. Yousef, "Modelling the smart city performance," Innov. Eur. J. Soc. Sci. Res., vol. 25, no. 2, pp. 137-149, 2012.

[10] T. Produk and D. Regional, "Perkembangan ekonomi sumatera barat," 2019.

[11] B. Pusat, Kota Padang Dalam Angka Tahun 2019, vol. 11, no. 3. 2020.

[12] A. Bakar, "IDENTIFIKASI SEKTOR EKONOMI UNGGULAN DI KABUPATEN MIMIKA PROVINSI PAPUA," J. Krit. (Kebijakan, Riset, dan Inovasi), vol. 1, no. 2, p. 5, 2017.

[13] W. Nowar, D. P. T. Baskoro, and B. Tjahjono, "Analisis Kesesuaian Lahan Komoditas Unggulan dan Arahan Pengembangannya di Wilayahkabupaten Cianjur," Tataloka, vol. 17, no. 2, pp. 87-98, 2015.

[14] A. Purwanto, J. Sušnik, F. X. Suryadi, and C. de Fraiture, "Determining strategies for water, energy, and food-related sectors in local economic development," Sustain. Prod. Consum., vol. 16, pp. 162-175, 2018, doi: https://doi.org/10.1016/j.spc.2018.08.005.

[15] M. M. Miller, L. J. Gibson, and N. G. Wright, "Location quotient: A basic tool for economic development analysis," Econ. Dev. Rev., vol. 9, no. 2, p. 65, 1991.

[16] X. Wang and R. Hofe, Research methods in urban and regional planning. Springer Science \& Business Media, 2008.

[17] S. Nazara and G. J. D. Hewings, "Spatial structure and taxonomy of decomposition in shift-share analysis," Growth Change, vol. 35, no. 4, pp. 476-490, 2004.

[18] J. P. Blair, Urban and regional economics. Homewood, Ill.: Irwin, 1991.

[19] L. Muta'Ali, “Teknik analisis regional untuk perencanaan wilayah, tata ruang dan lingkungan," Yogyakarta Badan Penerbit Fak. Geogr. Univ. Gadjah Mada, 2015.

[20] I. Buchori, O. R. Manullang, and Y. Basuki, "Metode Analisis Perencanaan." 2007.

[21] R. W. Jackson and K. E. Haynes, "Shift-Share Analysis," A. B. T.-I. E. of H. G. (Second E. Kobayashi, Ed. Oxford: Elsevier, 2020, pp. 199-205. 